\title{
The Role of Human Herpesvirus Type-6 (HHV-6) in Convulsions Seen in Children at Korle-Bu Teaching Hospital, Accra
}

\author{
Lennox-Mac Ankrah"1, Theophilus Adiku1*, Eben Badoe², \\ Kwamena William Coleman Sagoe ${ }^{1}$, Anna Aba Kafintu-Kwashie', Makafui Seshie ${ }^{1}$ \\ ${ }^{1}$ Department of Microbiology, University of Ghana Medical School, Accra, Ghana \\ ${ }^{2}$ Department of Child Health, Korle-Bu Teaching Hospital, Accra, Ghana \\ Email: lenny mac 2007@hotmail.com, \\ anahay@hotmail.com, mseshie@cha.edu.gh
}

Received 27 December 2013; revised 27 January 2014; accepted 7 February 2014

Copyright (C) 2014 by authors and Scientific Research Publishing Inc.

This work is licensed under the Creative Commons Attribution International License (CC BY).

http://creativecommons.org/licenses/by/4.0/

(c) (†) Open Access

\begin{abstract}
Background: Since the isolation of HHV-6 in 1986, extensive investigation has revealed it to be ubiquitous and responsible for the majority of cases of a common febrile rash illness of infants known as roseola. Other clinical associations including seizure disorders, encephalitis and meningitis have also been stated in various publications. Objective: The aim of the study is to find out if there is any association between HHV-6 infection and the convulsions prevailing at the Child Health Department of the Korle-Bu Teaching Hospital, Accra-Ghana. Methods and Results: Children admitted into the Department of Child Health with episode of convulsions were recruited after informed consent had been sought from subjects. Cerebrospinal fluid (CSF) and Plasma were obtained from patients. PCR directed at the detection of the large tegument protein (LTP) gene in the SIE strain of the HHV-6 in Plasma and CSF from patients was done. The mean age of study subjects was 37.44 months with $53(64.6 \%)$ being males. There was a significant relationship between the convulsions and fever $(P<0.05)$. Based on CSF characteristics gathered, viral infections may be the probable cause of the observed convulsions but not malaria or bacterial infections. None of the samples from the patients had evidence of HHV-6. Conclusion: The study was unable to establish HHV-6 infection in the CSF and Plasma of patients. What role if any HHV-6 has in convulsions seen in children or neurological diseases at large merits further studies. Other neurotropic viruses need to be investigated as possible causes for the convulsions.
\end{abstract}

\section{Keywords}

Convulsions; HHV-6; Large Tegument Protein (LTP) Gene; PCR; Neurological Diseases

\footnotetext{
${ }^{*}$ Corresponding author.

How to cite this paper: Ankrah, L.-M., et al. (2014) The Role of Human Herpesvirus Type-6 (HHV-6) in Convulsions Seen in Children at Korle-Bu Teaching Hospital, Accra. Open Journal of Medical Microbiology, 4, 77-89. 


\section{Introduction}

Epidemiological studies have shown HHV-6 to be a ubiquitous virus, with the majority of primary HHV-6 infections occurring within the first year of life [1] [2]. Since the identification of HHV-6, there have been several reports which suggest HHV-6 invades the central nervous system (CNS) and CNS manifestations including febrile seizures [3] [4]. Thus, HHV-6 is associated with neurological diseases but its contribution to the burden of severe forms of such illness in early childhood remains undetermined.

All herpesviruses become latent following primary infections, and sites of latency may vary. During latency, a limited number of viral genes are expressed. However, various stimuli can be awaken by the virus and stimulate the production of progeny virus [5]. For HHV-6, the primary sites of latency are the salivary glands and peripheral blood mononuclear cell (PBMCs). During primary infections, high concentrations of the virus can be found in the PBMCs [4] [6]. Thereafter viral DNA exists at very low concentrations in PBMCs and by using sensitive techniques; it can be identified in most adults. In addition, most individuals shed HHV-6 in the saliva [4] [6]. The central nervous system and genital tract appear to be other sites of HHV-6 latency [7] [8].

HHV-6 is probably the most neurotropic virus known [9]. Neuroinvasion has been documented in infants with primary infection, in focal encephalitis, in children and adults with AIDS, in recipients of bone marrow transplants, as well as in immunologically competent children and adults [9].

The role of HHV-6 in central nervous system (CNS) disease is an area of ongoing investigation. The range of CNS manifestations ascribed to this virus includes asymptomatic infection, febrile convulsions, seizure disorders, meningitis, meningoencephalitis, facial palsy, vestibular neuritis, demyelinating disorders, hemiplegia and rarely, fatal encephalitis [6] [10] [11]. Investigators have been unable to culture HHV-6 from cerebrospinal fluid (CSF) [10]. However, HHV-6 DNA has been detected in CSF and other body fluids by polymerase chain reaction (PCR), which implicates the virus in neurologic disorders [12].

Since 2004, cases of convulsion of unknown causative agent have been reported at the Child Health Department of the Korle-Bu Teaching Hospital (KBTH). Up to date, the actual etiological agent is unknown. Children between the ages of one month and ten years are usually faced with this condition with clinical presentations of fever, convulsion and with or without rash. Approximately fifteen cases are recorded every month. Since the actual causative agent that will give an idea of the appropriate drug to be used is unknown, only the symptoms are clinically managed leading to misuse of antibiotics and anti-malarial drugs. Parasitological and bacteriological investigations conducted on samples were usually negative, however, since HHV-6 has been associated with convulsions, it will be important to investigate its role in the convulsions seen in these Ghanaian children.

The objectives of this study were to identify the demographic and epidemiological factors associated with convulsions not associated with malaria or bacterial infections and to determine HHV-6 prevalence in children with convulsions not associated with malaria or bacterial infections.

\section{Materials and Methods}

\subsection{Description of Study Site}

The Korle-Bu Teaching Hospital (KBTH) is the largest teaching hospital and major referral health facility in Ghana. It is located in the Greater Accra region of the country. The study was conducted from July 2010 to April 2011.

\subsection{Study Subjects and Case Definition}

Children between the ages of one month and ten years admitted to the hospital having fever, convulsion and with or without skin rash were recruited for the study after informed consent had been obtained from their parents. All children with convulsions [both simple (1 - 15 minutes without recurrence) and complex (>15 minutes with or without recurrence], fever (with or without skin rash) and other neurological manifestations; were included in the study.

Children with metabolic abnormality, non viral meningitis, non viral encephalitis and other neurological diseases with a non-infectious cause; were excluded from the study.

Some of the patients who failed to satisfy the inclusion criteria were recruited as controls. Although samples from such patients were not collected, data such as age, gender, temperature, and fever status at onset of reported disease, family history of sickle cell disease, diabetes, asthma and convulsion in first degree relatives 
were retrieved from their folders to aid in analysis of data retrieved from study subjects.

The proposal was submitted to the Ethical Committee of the College of Health Sciences, and Research Committee of the University of Ghana Medical School (UGMS) for approval. Informed consent was sought from subjects before the commencement of the study. Data collected from the study was handled anonymously and confidentially. Samples had only the identification numbers of the subjects to ensure anonymity.

\subsection{Sample Collection}

About $1 \mathrm{ml}$ - $2 \mathrm{ml}$ of CSF, whole blood or both were collected and transported on ice to the Virology Unit of the Microbiology Department at the KBTH. Plasma was obtained from whole blood samples after which the CSF and plasma samples were stored at $-20^{\circ} \mathrm{C}$ until analyzed.

\subsection{DNA Extractions}

\subsubsection{DNA Extraction from CSF}

DNA extraction from CSF was done using the High Pure viral nucleic acid kit from Roche Diagnostics according to the manufacturer's instructions. To a sterile microcentrifuge tube containing $200 \mu \mathrm{l} \mathrm{CSF}$ sample, $200 \mu \mathrm{l}$ binding buffer supplemented with poly A and $50 \mu$ proteinase $\mathrm{K}$ was added. Mixing was done immediately and the mixture incubated at $72^{\circ} \mathrm{C}$ for 10 minutes. After incubation, $100 \mu \mathrm{l}$ binding buffer was added. The lysate was then pipetted into the upper reservoir of a combined High pure filter and collection tube. Centrifugation was done for 1 minute at $8000 \times \mathrm{g}$ and the flow through together with the collection tube discarded. $500 \mu \mathrm{l}$ inhibitor removal buffer was added, centrifugation done at $8000 \times \mathrm{g}$ for 1 minute and flow through together with the collection tube discarded. The inhibitor removal buffer helps to get rid of PCR contaminants. This was followed by two washing steps with $450 \mu \mathrm{l}$ wash buffer accompanied by centrifugation at $8000 \times \mathrm{g}$ for 1 minute to aid wash bound nucleic acids, purifications from proteins and other impurities. After the final washing step, the collection tube and flow through was discarded and further centrifugation was done at maximum speed $(13,000 \times \mathrm{g})$ for 10 seconds. Purified nucleic acids were recovered using $50 \mu \mathrm{l}$ elution buffer and stored at $-20^{\circ} \mathrm{C}$.

\subsubsection{DNA Extraction from Plasma}

DNA was extracted from plasma samples using PureLink ${ }^{\mathrm{TM}}$ viral RNA/DNA kit from Invitrogen according to manufacturer's instructions. To a sterile microcentrifuge tube containing $25 \mu$ l Proteinase K, $200 \mu \mathrm{l}$ cell free sample was added. This was followed by the addition of $200 \mu \mathrm{l}$ lysis buffer containing carrier RNA and vortexing for 15 seconds, then incubation at $56^{\circ} \mathrm{C}$ for 15 minutes. $250 \mu \mathrm{l}$ of $96 \%-100 \%$ ethanol was added and vortexed for 15 seconds. The lysate was then added to the viral spin column in a collection tube. Centrifugation was then done at $6800 \times \mathrm{g}$ for 1 minute. The flow through and collection tube was then discarded. Two washing steps were then done using $500 \mu \mathrm{l}$ wash buffer with ethanol accompanied by centrifugation at $6800 \times \mathrm{g}$ for 1 minute. The spin column was then centrifuged at maximum speed for 1 minute to remove any residual wash buffer. The purified nucleic acid was then eluted in 10 - $50 \mu \mathrm{l}$ sterile RNase free water and stored at $-20^{\circ} \mathrm{C}$ until used for the desired downstream application.

\subsection{HHV6 PCR}

The PCR reaction was directed at the detection of the large tegument protein (LTP) gene in the SIE strain of the HHV-6 [13]. PCR Primers used are as follows;

SIE-1 5'GATCCGACGCCTACAAACAC3'

SIE-2 5'TACCGCATCCTTGACATATTAC3'

This set of primers detects both HHV-6 variants A and B [13]. DNA was amplified in a total volume of 100 $\mu \mathrm{l}$ of a reaction mixture including $25 \mathrm{mM} \mathrm{MgCl}_{2}$ (Roche), 10× PCR buffer (Roche), glycerol, $10 \mathrm{mM}$ dNTPs (Applied Biosystems)), 5U Taq polymerase (Invitrogen), 83 pmol primers (Applied Biosystems) and extracted DNA (template).

Ninety microlitres of master mix was aliquoted into $0.2 \mathrm{ml}$ sterile PCR tubes and $10 \mu \mathrm{l}$ of template added to each tube. Sterile PCR water was used as negative control and HHV-6 control DNA from Advanced Biotechnologies Inc. (USA) was used as positive control. The sample was amplified through 40 cycles in a DNA thermal cycler (MJ Research mini cycler) with a 5 min hot start at $95^{\circ} \mathrm{C}$, followed by 30 sec denaturation step at $94^{\circ} \mathrm{C}$, 30 sec annealing step at $55^{\circ} \mathrm{C}, 1$ min elongation step at $72^{\circ} \mathrm{C}$ and a final extension at $72^{\circ} \mathrm{C}$ for $10 \mathrm{~min}$. Ten 
microlitres of extracted DNA was used as template.

The amplified products were electrophoresed ( $80 \mathrm{~V}$ for 1 hour) by agarose gel ( $2 \% \mathrm{w} / \mathrm{v}$ ) stained in $0.5 \mu \mathrm{g} / \mathrm{ml}$ ethidium bromide with a $1 \mathrm{~kb}$ DNA marker. The fractionated bands were visualized under UV light. The expected size for a positive amplification product is $249 \mathrm{bp}$.

\subsection{Statistical Analysis}

Data was entered using Microsoft Excel 2007 and analyzed using Graph Pad Prism. Analysis of clinical data was done using descriptive statistics for frequency distribution and Chi-Square test was used where appropriate. Statistically significant difference was reported for a two-tailed p-value lower than 0.05 .

\subsection{Quality Control}

\subsubsection{Determination of Extraction Kits Efficiency}

To ascertain the efficiency of the extraction kits used, Human Parvovirus B19 positive plasma sample (WHO Standard positive control) was extracted using both Pure Link ${ }^{\mathrm{TM}}$ viral RNA/DNA and High Pure viral nucleic acid kits from Roche and Invitrogen respectively. At least one B19 positive plasma sample was added to every batch of extraction done and extracted alongside the samples. The HPV B19 DNA extracted was then taken through Semi-nested PCR using the appropriate primers under optimized conditions. The amplicons were then electrophoresed and products viewed under the UV transilluminator. The primers used for the semi-nested PCR are as follows as stated elsewhere [14].

First round amplification

GAPS(forward): 5'-ATGGACAGTTATCTGACCACCCCC-3'

USTO(reverse): 5'-GCTGGGGTATTTTTCCGAGGCGT-3'

\section{Second round amplification}

GAPSi(forward-inner-primer): 5'-GTATTATCTAGTGAAGACTTACACAA-3'

USTO(reverse): 5'-GCTGGGGTATTTTTCCGAGGCGT-3'

The semi-nPCR for B19 HPV targets the C-terminal part of the VP1u region with an expected product size of 358 bp [14].

DNA was amplified in a total volume of $25 \mu \mathrm{l}$ of a reaction including $10 \times$ PCR buffer with $\mathrm{Mg}^{2+}, 10 \mathrm{mM}$

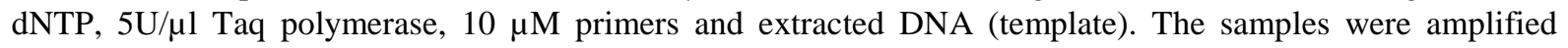
through 35 cycles in a thermal cycler (MJ Research mini cycler) with a 5 min hot start at $95^{\circ} \mathrm{C}$, followed by 30 sec denaturation step at $95^{\circ} \mathrm{C}, 40 \mathrm{sec}$ annealing step at $57^{\circ} \mathrm{C}, 50$ sec elongation step at $72^{\circ} \mathrm{C}$ and a final extension at $72^{\circ} \mathrm{C}$ for $7 \mathrm{~min}$. Five microlitres of extracted DNA was used in the first round amplification and $2.5 \mu \mathrm{l}$ of the first round product was used in the second round amplification.

\subsubsection{Optimization of HHV-6 PCR}

HHV-6 DNA positive control obtained from Advanced Biotechnologies Inc. in the USA was used to optimize and estimate the sensitivity of the PCR. The controls $\left(1-2 \times 10^{4}\right.$ copies $\left./ \mu \mathrm{L}\right)$ were used as templates and run alongside the samples. They were included in every batch of samples run and the amplicons electrophoresed and visualized under UV transilluminator.

All control extractions done were B19 positive for both Pure Link ${ }^{\mathrm{TM}}$ viral RNA/DNA and High Pure viral nucleic acid extraction kits as seen in Figure 1. This confirms that both extraction kits are very efficient and that every batch of DNA extraction done was successful.

The HHV 6 control DNA used in the HHV-6 PCR also gave the required band size of positive amplification for every batch of samples run as seen in Figure 2.This connotes that the HHV-6 PCR system was fully optimized and that the primers were specific.

\section{Results}

The result in Table 1 shows that a total of 82 children were recruited for the study. In all, 107 samples were collected; 41 plasma samples and 66 CSF samples. Twenty-five of the CSF and plasma samples were from same patients (paired samples).

Majority of children were males 53 (64.6\%) whiles 29 (35.4\%) were females. Thirty (36.59\%) of the children 


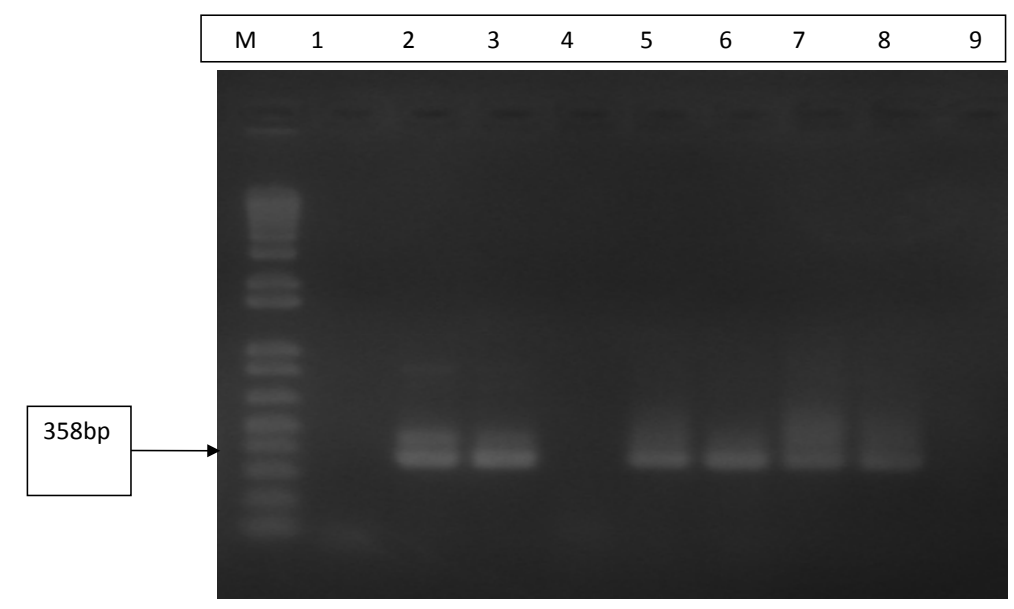

Figure 1. Gel electrophoresis pattern of extraction controls (B19). Lane M is with 100 bp molecular marker (ladder). Lane 1 is with negative control (extraction from NHP) and Lane 4 also with negative control $\left(\mathrm{d}_{2} \mathrm{O}\right)$. Lane 2 is with B19 DNA positive control (358 bp). Lanes 3 and 5 are with extraction controls (Pure Link ${ }^{\mathrm{TM}}$ viral RNA/DNA kit). Lanes 6, 7 and 8 are with extraction controls (High Pure viral nucleic acid kit).

Table 1. Sample type distribution of patients.

\begin{tabular}{cc}
\hline SAMPLE TYPE & NUMBER OF PATIENTS \\
\hline Paired Samples (Plasma/CSF) & 25 \\
Plasma only & 16 \\
CSF only & 41 \\
TOTAL & 82 \\
\hline
\end{tabular}

belong to the 0 - 12 months age group and 62 (75.6\%) of all subjects were 60 months (5 years) and below as shown in Figure 3. From the result in Table 2, it can be seen that the minimum age and maximum age of subjects was 0.5 months ( 2 weeks) and 120 months respectively.

Among the patients recruited for the study, 62 (75.6\%) had fever whiles 20 (24.4\%) had no fever. The maximum and minimum body temperatures of patients were $40.0^{\circ} \mathrm{C}$ and $36.4^{\circ} \mathrm{C}$ respectively with a mean of $38.05^{\circ} \mathrm{C}$ as shown in Table 2.

Of the 82 patients studied; 46 (56.1\%) presented with febrile convulsion and convulsion without any known cause, 26 (31.7\%) presented with convulsion with meningitis and 10 (12.2\%) presented with convulsion with gastroenteritis. All the presumptive diagnosis fall under "convulsion of unknown cause" since the actual cause of the meningitis and gastroenteritis accompanying the convulsions is unknown. Data on clinical and medical history such as blood transfusion, sickle cell disease status, diabetes mellitus, asthma and family history of convulsion displayed in Table 3 shows that a family history of convulsion in first degree relatives was observed in 4/47 (8.5\%) of the study population whiles $43 / 47$ (91.5\%) did not have any family history of convulsion. Family history of other clinical conditions of subjects are also displayed in the same table. Fifty-five (67.1\%) of the subjects do not breast feed whiles 27 (32.9\%) feed on breast milk. Ten (12.3\%) of the patients had CNS disorder.

Of the 82 patients studied, information on nature of convulsion was available for 47 patients. Nine (19.1\%) suffered recurrence of convulsion at different times whiles 38 (80.9\%) had no recurrence of the condition. Fortyone (87.2\%) presented with simple convulsion (1 - 15minutes) and 6 (12.77\%) presented with complex convulsion (15minutes).

The result in Table 4 shows the CSF characteristics of study subjects. The CSF characteristics of exactly half of the total number of patients were available for analysis. The characteristics considered include; appearance of CSF, level of protein and glucose in CSF, white blood cell and red blood cell counts. Majority of the patients 29 (70.7\%) had their CSF appearance to be clear and colourless whiles 8 (19.5\%) and 4 (9.8\%) were hazy and 


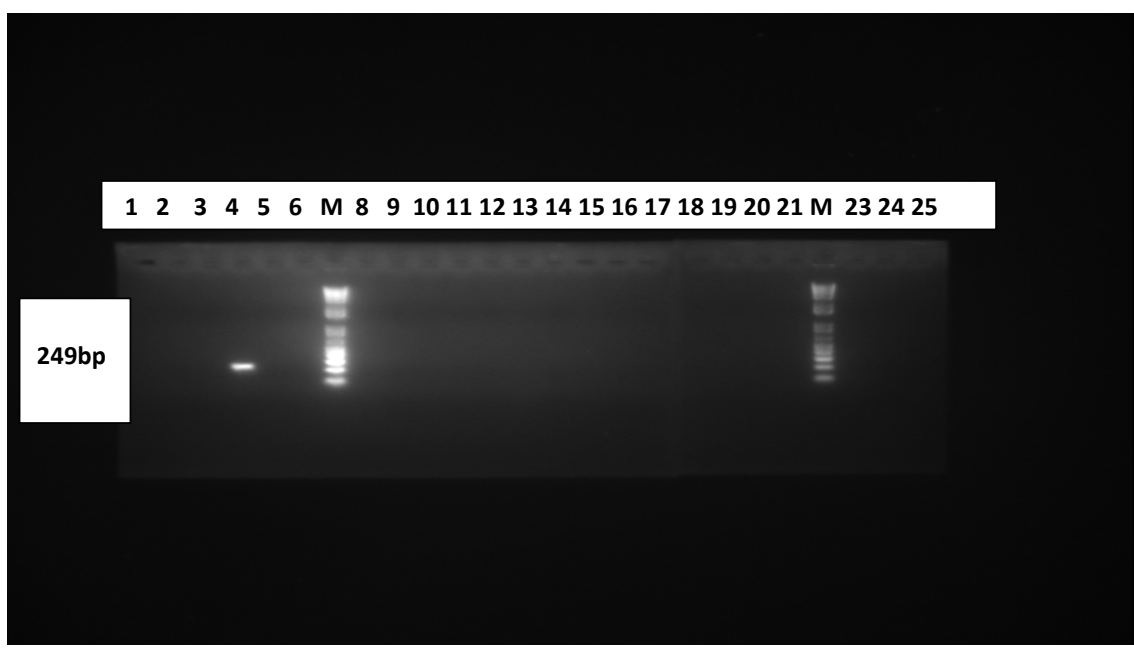

Figure 2. Gel electrophoresis pattern of CSF and Plasma samples. Lanes 7(M) and 22(M) are with $100 \mathrm{bp}$ molecular marker (ladder). Lanes 4 and 23 are with positive control (249 bp) and negative control (PCR water) respectively. Lanes 1 - 12 are with products from plasma samples and 13 - 25 are with products from CSF samples (excluding the marker and control lanes).

\begin{tabular}{|c|c|c|c|c|c|}
\hline VARIABLE & MEAN & SD & RANGE & MAX & MIN \\
\hline AGE (MONTHS) & 37.44 & 35.58 & 119.5 & 120 & 0.50 \\
\hline TEMPERATURE $\left({ }^{\circ} \mathrm{C}\right)$ & 38.05 & 1.10 & 3.60 & 40 & 36.4 \\
\hline
\end{tabular}

blood stained respectively. Six (14.6\%) of the subjects had high glucose level while 35 (85.4\%) had normal glucose level. Normal protein level was found in 29 (70.7\%) whiles high protein level was found in 12 (29.3\%).

The result in Figure 2 indicates that the study was unable to establish HHV-6 infection in subjects with all showing negative results for the viral DNA. HHV-6 DNA was absent in all the CSF and Plasma samples.

\section{Discussion}

Several researchers have tried to investigate a number of epidemiological and demographic factors which could be associated with convulsions and varying reports have arisen from these investigations [15]-[20].

In the current study, statistically, there was no significant difference $(P=0.2114)$ between cases and controls regarding gender. This finding correlates with study conducted by Mahyar et al., [19] where 53 (66\%) and 27 (34\%) were males and females respectively. Even though several studies support the finding of male dominance in convulsion [17] [20]-[23], their respective proportions of males may seem lower than that observed in the current study. In the current study, male gender was not found to be a risk factor for convulsion in children. Contrasting results have been reported elsewhere where male gender was found to be a risk factor [15].

Various researches point to the fact that age is a risk factor for convulsion [21] [24]. In the current study, peak incidence of convulsion was found in the age group 0 - 12 months. Farwell et al., [24] had majority of their cases between 12 and 23 months of age. A recent study also showed a peak incidence between the ages of 13 and 24 months of age [21]. The general trend seen in both studies and the present study is that convulsion commonly occurs in children with peak incidence at age $0-24$ months. This may probably be due to the fact that the developing brain has a lower seizure threshold to the destabilizing effects of temperature elevation.

In the present study, it was observed that $62(75.60 \%)$ of the patients with convulsion had fever whiles 24 (30\%) of the controls had fever. This finding was statistically significant $(\mathrm{P}<0.05)$. Sixty $(73.17 \%)$ of the cases had their fever level (body temperature) $\geq 38^{\circ} \mathrm{C}$ whereas $13(16.25 \%)$ of the controls had their fever level $\geq 38^{\circ} \mathrm{C}$. This finding is in accordance with a study carried out by Ling [18] who studied 379 patients with convulsion and found out that $257(68.17 \%)$ had their fever level $\geq 38^{\circ} \mathrm{C}$. The slight difference observed may be probably due to 
Table 3. Clinical data and medical history of study population versus control population.

\begin{tabular}{|c|c|c|}
\hline \multirow[t]{2}{*}{ VARIABLE } & \multicolumn{2}{|c|}{ NUMBER OF PATIENTS (\%) } \\
\hline & $\begin{array}{c}\text { STUDY } \\
\text { POPULATION }\end{array}$ & $\begin{array}{l}\text { CONTROL } \\
\text { POPULATION }\end{array}$ \\
\hline \multicolumn{3}{|l|}{ Blood transfusion history } \\
\hline Yes & $10(12.2)$ & \\
\hline No & $72(87.8)$ & 75 (93.75) \\
\hline \multicolumn{3}{|l|}{ Fever status } \\
\hline Fever & $62(75.6)$ & $24(30)$ \\
\hline No fever & $20(24.4)$ & $56(70)$ \\
\hline \multicolumn{3}{|l|}{ Sickle Cell Disease } \\
\hline Positive & $4(4.9)$ & $6(7.5)$ \\
\hline Negative & $78(95.1)$ & $74(92.5)$ \\
\hline \multicolumn{3}{|l|}{ Diabetes mellitus history } \\
\hline Positive & $2(2.4)$ & $0(0)$ \\
\hline Negative & $80(97.6)$ & $80(100)$ \\
\hline \multicolumn{3}{|l|}{ Asthma history } \\
\hline Positive & $10(12.2)$ & $6(7.5)$ \\
\hline Negative & $70(87.8)$ & $74(92.5)$ \\
\hline \multicolumn{3}{|l|}{ Feeding } \\
\hline Breastfeeding & 27 (32.9) & $34(42.5)$ \\
\hline Other foods (Bottle feeding) & $55(67.1)$ & $46(57.5)$ \\
\hline \multicolumn{3}{|l|}{ Type of convulsion } \\
\hline Simple & $41(87.2)$ & \\
\hline Complex & $6(12.8)$ & \\
\hline \multicolumn{3}{|l|}{ Convulsion in family } \\
\hline Positive & $4(8.5)$ & \\
\hline Negative & $43(91.5)$ & \\
\hline \multicolumn{3}{|l|}{ Recurrence of convulsion } \\
\hline Yes & $9(19.1)$ & \\
\hline No & 38 (80.9) & \\
\hline
\end{tabular}

Table 4. CSF characteristics of study subjects.

\begin{tabular}{ccc}
\hline $\begin{array}{c}\text { CSF } \\
\text { CHARACTERISTICS }\end{array}$ & RESULTS & NUMBER OF \\
PATIENTS(\%) \\
\hline APPEARANCE & Clear/Colourless & $29(70.7)$ \\
& Hazy & $8(19.5)$ \\
PROTEIN LEVEL & Blood stained & $4(9.7)$ \\
& Normal & $29(70.7)$ \\
GLUCOSE LEVEL & Decreased & $12(29.3)$ \\
& Normal & $0(0)$ \\
WHITE BLOOD & Increased & $35(85.4)$ \\
CELLS & Decreased & $6(14.6)$ \\
& Normal & $0(0)$ \\
RED BLOOD CELLS & Increased & $37(90.2)$ \\
& Decreased & $4(9.8)$ \\
\hline
\end{tabular}




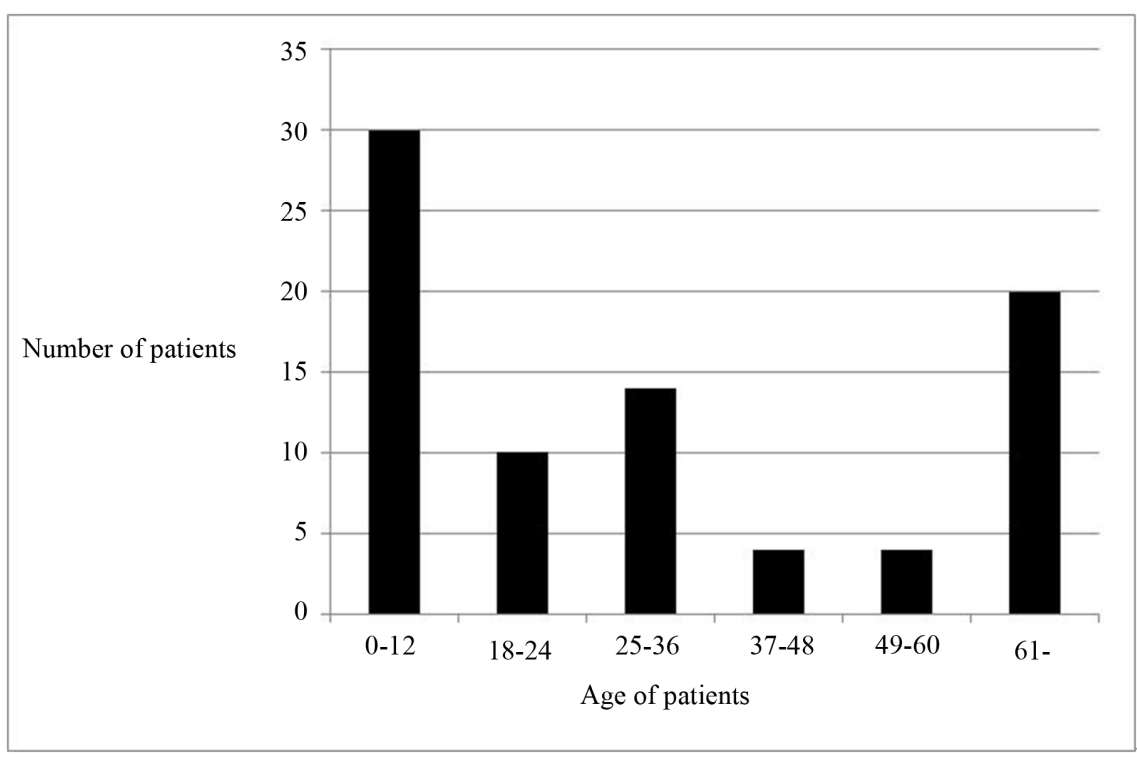

Figure 3. Age distribution of subjects.

the relatively large sample size used in the study as compared to the present study. Despite this finding, it seems unlikely that fever as a single factor can induce convulsions since children with diseases causing high fever such as bronchopneumonia and pyelitis rarely suffer from convulsions [25] [26].

Studies done elsewhere showed that between 9\% - 35\% of convulsions are complex [22] [27] [28]. Kwong et al., and Chung et al., in their studies had $15 \%$ and $16 \%$ of their study subjects with complex convulsions respectively [29] [30]. In the current study, 6 (12.77\%) of the subjects presented with complex convulsion which is almost in the same range as Kwong et al., [30] and Chung et al., [29]. Kong and Ko et al., [31] and Chan [32] had a relatively higher proportion (23\% and $23.3 \%$ respectively) of their study subjects showing complex convulsions. The present study however correlates perfectly with a study carried out by Tosun et al., [33] where of the 259 children with convulsion, 33 (12.7\%) were diagnosed with complex convulsion. Studies of this nature that require contribution of caregivers of study subjects are affected by the inability of some caregivers to give exact duration of convulsion when it first occurred. This brings about slight inaccuracies and probably the reason for the differences observed in the present study and other studies.

Chung et al., and Chan reported recurrence of convulsion in $18 \%$ and $22 \%$ of patients studied respectively [29] [32]. The current study where 9 (19.15\%) of study subjects showed recurrence of convulsion fall in the same range as these two studies. Bener et al., [15], in their study however recorded a higher proportion 24 (34.3\%) of study subjects with recurrent convulsion.

In the current study, children with recurrent convulsion were found to have lower body temperature than those with first attack. This is in agreement with a Nigerian study which also found that at each recurrent seizure, children had low rectal temperatures [34].

Convulsions tend to occur in families, although the exact mode of inheritance is unknown Children who have convulsion tend to have a history of convulsion in close relatives [35]. In the present study, a family history of convulsion in the first degree relatives was observed in 4 (8.51\%) of study subjects. This is lower than what was observed by many studies which reported family history of convulsion in $17 \%-21 \%$ of convulsion subjects [29] [31] [32] [36]. The difference may be due to the fact that these studies concentrated exclusively on febrile convulsions whiles the present study was on convulsions in general. It has long been recognized that there is a significant genetic component for susceptibility to febrile convulsion. An autosomal dominant febrile convulsion gene locus has been reported on chromosome 19p [37]. Another reason for the observed variations may be due to the inability of some caregivers to give accurate responses to questions concerning medical history of subjects.

There was no statistically significant difference between cases and controls regarding blood transfusion history $(\mathrm{P}=0.3011)$, sickle cell disease status $(\mathrm{P}=0.7138)$, asthma $(\mathrm{P}=0.3011)$, diabetes mellitus history $(\mathrm{P}=$ $0.4877)$ and feeding $(\mathrm{P}=0.2735)$. This connotes that there is no significant relationship between these variables 
and the convulsion seen in children under the current study. These variables were also not found to be risk factors for convulsion.

Lumber puncture is commonly performed in patients who have had an acute seizure to evaluate for evidence of CNS infection as an underlying cause [38]-[40]. Interpretation of CSF finding in the context of this study is complicated by the possibility that convulsions in themselves may alter CSF making it difficult to determine whether the abnormality is due to seizures or an underlying infection [41]. Seizures have been reported to induce postictal pleocytosis, neutrophilia and increased CSF protein [41]-[43]. The present study also revealed that 12 (29.26\%) of subjects had increased CSF protein level whiles none had low CSF protein. This confirms that convulsions are linked in some way to increased CSF protein as stated in literature. CSF analysis in convulsion patients have shown increased concentration of glucose [44]. The current study had none of its subject with low CSF glucose whiles 6 (14.63\%) had increased CSF glucose level. Hyperglycemia is regarded as consequences of convulsion induced release of both cortisol and adrenalin. Rapid release of cortisol and adrenaline as a stress reaction induces elevated glucose concentration in blood and CSF [45]. Much weight cannot be put on the glucose level finding in the current study since blood glucose level in patients during disease onset was not noted. CSF glucose is normally approximately $2 / 3$ of the fasting plasma glucose. A blood sample for glucose must ideally be taken at the same time as the lumber puncture for CSF-serum ratio to be computed for proper analysis of CSF glucose level to be done.

Viral infections such as HHV6 which is the focus of this study has been shown to be characterized by clear and colourless CSF, raised or high end of normal CSF protein level, normally within normal range glucose level and absence of organisms in CSF gram stain. Viruses unlike bacteria grow in living cells and do not need macromolecules like protein and glucose to grow. For this reason in a typical viral infection, protein level and glucose level are normal or slightly increased. Majority of the study subjects showed these parameters which probably indicate that the convulsion may likely be due to a viral infection but not malaria or bacterial infection.

The study recorded an increase in WBC's of four patients. The number of WBC's in CSF is very low, usually necessitating a manual WBC count. An increase in WBC count may occur in many conditions including infection, allergy and leukemia. Differential WBC count is therefore needed to help distinguish these causes. For example, viral infections are usually characterized by an increase in lymphocytes. Data on WBC differential count was not available on the study subjects, limiting the interpretation of WBC count.

In the current study, none of the patients tested had HHV6 DNA in the CSF or Plasma. HHV-6 is very cell associated [46], which means there is very little free virus spilled in the serum, plasma and CSF in an active infection. This is because the virus is spread from cell to cell through the cell walls. This is in contrast to other infections where free virus leave the cell, enters the plasma and then infects another cell. The absence of HHV6 DNA in the plasma of patients studied probably reveal the absence of active infection. This does not however rule out the presence of the virus in them. Nearly $100 \%$ of individuals have been infected with HHV-6 by early childhood and have antibodies against it [47]. At least 30\% of individuals have small but detectable levels of latent virus in their blood. The relevant question when it comes to whole blood is not whether you have the virus but rather how much of the virus you have and whether it is active or latent? Since so many healthy individuals have detectable levels of latent virus in their white blood cells, PCR DNA tests of whole blood are not useful unless the test is quantitative and the absolute level of the virus can be compared to a healthy population. In Plasma and serum however the mere presence of the DNA of the virus denotes active infection.

A high proportion of children with past HHV-6 infection retain the viral DNA in their CSF suggesting that the CNS may be a reservoir for persistent infection. Studies pointing to this fact suggest persistent infection of the CNS by HHV-6 of many persons long after primary infection. The current study had none of its subjects with HHV-6 DNA in CSF.

The absence of the HHV-6 DNA in the CSF and/or plasma of study subjects may be attributed to the fact that the age distribution of the present study might have resulted in a selection bias against HHV-6 detection. The median age of primary HHV-6 infection is 8 - 9 months [48]. In the current study only $\leq 30$ (approximately $36.59 \%$ ) of the patients were younger than 12 months old. Secondly the PCR procedure may not have been sufficiently sensitive to detection of low levels of viral genome since HHV-6 is very cell associated and so very minute level of the virus is found in cell free samples. Thirdly, the convulsions may have occurred independently of HHV-6 infection. In other words, the seizures were induced by fever caused by the infections and not by some specific neurotropic property unique to the viruses. Lastly, the convulsion might have occurred without direct invasion of the central nervous system or the CSF but instead because of a viral induced vasculities as part 
of the viral infection [49]. It may also be that the viral genome might have passed through the CSF either before or after the seizure occurs.

Some researchers have reported successful detection of HHV-6 from CSF of a small number of patients with febrile seizures using the PCR. Caserta et al., [6] for example, detected HHV-6 DNA from the CSF of two of such patients younger than 3 years of age with primary HHV-6 infection and 11 of such patients with evidence of previous HHV-6 infection. Hall et al., [48] reported detection of HHV-6 DNA in two of seven patients with febrile seizures (primary or recurrent not specified). Chua et al., [16] also reported HHV-6 detection in 16.1\% (5/31) of children with febrile convulsions studied at the University Hospital, Kuala Lumpur. Malaysia.

Other research groups have reported results of HHV-6 detection similar to the current study's findings. Hukin et al., [50] for example, were unable to detect HHV-6 in the CSF of 15 patients with febrile seizures either by PCR or culture. Teach et al., [49] were also unable to detect HHV-6 DNA in the CSF of patients with febrile convulsion studied. Barone et al., [10] also reported similar findings. Why some groups have successfully detected HHV-6 and others have not is unclear. Possible explanations for this include the sensitivity and specificity of the particular assays, the number of primary versus recurrent seizures studied, the ages of the patients studied or the effects of random sampling [49].

Studies of this nature where no positive results come out may raise some few questions regarding quality control systems put in place to ensure that the viral DNA is detected if indeed it was present. These questions have been fully answered in this study relating to storage of samples and extracted DNA at appropriate temperatures to prevent degradation, controlling of extraction procedure and finally optimization of the PCR system before samples were run.

The intended study design for sample collection was to obtain both Plasma and CSF from every patient recruited for the study. However that proved to be very difficult since many of the caregivers refused the participation of their wards. Most of them were so worried about the state of their wards since convulsion is a frighttening experience. Parents had little or no option when it comes to the CSF sample because CSF cannot be requested by a researcher purposely for research since the procedure is invasive. CSF samples were requested for by senior doctors and as a result a small portion is normally given out for the research. For the whole blood sample several tests are done and so little or none is normally left. This situation posed a lot of problems during the sample collection since many of the caregivers do not understand the importance of research and this resulted in an unequal number of CSF and plasma samples.

\section{Conclusions}

The study was unable to confirm the presence HHV-6 in the CSF and plasma of children with convulsions in Ghana. The role of HHV-6 in the pathogenesis of convulsions merits further studies.

It is recommended that the prevalence of HHV-6 be investigated in children (0 to 10 years) since the prevalence in the country is unknown and due to the epileptic potential of the virus.

The herpesvirus group (HSV-1, HSV-2, VZV, CMV and HHV-7) and other neurotropic viruses are of importance in relation to convulsions and epilepsy and must all be investigated. Subsequent studies should consider children with convulsions in general so that co-infection with other agents can also be accounted for.

\section{Acknowledgements}

We acknowledge the staff in the emergency ward of the Child Health Department for provision of samples for this study and the Virology section of the Department of Microbiology for their immense support. We wish to also acknowledge the HHV-6 Foundation in the United States of America and the University of Ghana Medical School for funding the study.

\section{References}

[1] Brown, N.A., Sumaya, C.V., Liu, C.R., Ench, Y., Kovacs, A., Coronesi, M. and Kaplan, M.H. (1988) Fall in Human Herpesvirus-6 Seropositivity with Age. Lancet, 332, 396-397. http://dx.doi.org/10.1016/S0140-6736(88)92864-4

[2] Knowles, W.A. and Gardner, S.D. (1988) High Prevalence of Antibody to Human Herpesvirus-6 and Seroconversion Associated with Rash in Two Infants. Lancet, 332, 912-913. http://dx.doi.org/10.1016/S0140-6736(88)92522-6

[3] Suga, S., Yoshikawa, T., Asano, Y., Kajita, Y., Ozaki, T., Yazaki, T., Nakashima, T., Yamada, A., Challoner, P.B., 
Smith, K.T. and Parker, J.D. (1993) Clinical and Virological Analyses of 21 Infants with Exanthema Subitum (Roseola Infantum) and Central Nervous System Complication. Annals of Neurology, 33, 597-603. http://dx.doi.org/10.1002/ana.410330607

[4] Asano, Y., Suga, S., Yoshiekawa, T., Yazaki, T. and Uchikawa, T. (1995) Clinical Features and Viral Excretion in an Infant with Primary Human Herpesvirus-7 Infection. Pediatrics, 95, 187-190.

[5] Pellet, P. and Roizman, B. (2007) Herpesviridae: A Brief Introduction. In: Howley, P., Ed., Fields Virology, 5th Edition, Lippincott, Philadelphia, 2480-2499.

[6] Caserta, M.T., Hall, C.B., Schnabel, K., CIntyre, K., Long, C., Costanzo, M., Dewhurst, S., Insel, R. and Epstein, L.G. (1994) Neuroinvasion and Persistence of Human Herpesvirus 6 in Children. The Journal of Infectious Diseases, 170, 1586-1589. http://dx.doi.org/10.1093/infdis/170.6.1586

[7] Leach, C.T., Newton, E.R., McParlin, S. and Jenson, H.B. (1994) Human Herpesvirus-6 Infection of the Female Genital Tract. The Journal of Infectious Diseases, 169, 1281-1283. http://dx.doi.org/10.1093/infdis/169.6.1281

[8] Okuno, T., Oishi, H., Hayashi, K., Nonogaki, M., Tanaka, K. and Yamanishi, K. (1995) Human Herpesviruses-6 and 7 in Cervixes of Pregnant Women. Journal of Clinical Microbiology, 33, 1968-1970.

[9] Campadelli-Fiume, G., Mirandola, P. and Menotti, L. (1999) Human Herpes Virus 6: An Emerging Pathogen. Emerging Infectious Diseases, 5. http://dx.doi.org/10.3201/eid0503.990306

[10] Barone, S.R., Kaplan, M.H. and Krilov, L.R. (1995) Human Herpesvirus-6 Infection in Children with First Febrile Seizures. Journal of Pediatrics, 127, 95-97.http://dx.doi.org/10.1016/S0022-3476(95)70263-6

[11] Osman, H. (2000) Human Herpesvirus 6 and Febrile Convulsions. Herpe, 7, 33-37.

[12] Asad, A., Li, S.B., Mark, J.A. and Adriana, W. (2004) Human Herpes Viruses 6 and 7 and Central Nervous System Infectious in Children. Emerging Infectious Diseases, 10. http://dx.doi.org/10.3201/eid1008.030788

[13] Cone, R.W., Huang, M.W., Hackman, R.C. and Corey, L. (1996) Coinfection with Human Herpes Virus 6 Variants A and B in Lung Tissue. Journal of Clinical Microbiology, 34, 877-881. http://dx.doi.org/10.1056/NEJM199307153290302

[14] Parsyan, A., AddoYobo, E., Owusu-Ofori, S., Akpene, H., Sarkodie, F. and Allain, J.P. (2006) Effects of Transfusion on Human Erythrovirus B19 Susceptible or Infected Pediatric recipients in a Genotype 3 Endemic Area. Transfusion, 46, 1593-1600. http://dx.doi.org/10.1111/j.1537-2995.2006.00952.x

[15] Bener, A., Al-Suweidi, E.E.K., Bessisso, M., Al-Gazali, L.I. and Al-Khider, A. (2006) Genetics and Environmental Risk Factors Associated with Febrile Seizure. Journal of Pediatric Neurology, 4, 239-243.

[16] Chua, K.B., Lam, S.K., AbuBakar, S., Koh, M.T. and Lee, W.S. (1997) The Incidence of Human Herpesvirus 6 Infection in Children with Febrile Convulsion Admitted to the University Hospital. Kuala Lumpur, Medical Journal of Malaysia, 52, 335-341.

[17] Gururaj, A.K., Bener, A., Al-Suweidi, E.K., Al-Tatari, H.M. and Khadir, A.E. (2001) Predictors of Febrile Seizure: A Matched Case-Control Study. Journal of Tropical Pediatrics, 47, 361-362. http://dx.doi.org/10.1093/tropej/47.6.361

[18] Ling, S.G. (2000) Clinical Characteristics and Risk Factors for a Complex First Febrile Convulsion. Singapore Medical Journal, 40, 264-267.

[19] Mahyar, A., Ayazi, P., Fallahi, M. and Javadi, A. (2010) Risk Factors of the First Febrile Seizures in Iranian Children. International Journal of Peadiatrics, Article ID: 862897. http://dx.doi.org/10.1155/2010/862897

[20] Pavlidou, E., Tzitiridou, M., Kontopoulos, E. and Panteliadis, C.P. (2008) Which Factors Determine Febrile Seizure Recurrence? A Prospective Study. Brain \& Development, 30, 7-13. http://dx.doi.org/10.1016/j.braindev.2007.05.001

[21] Bessiso, M.S., Cindro, L. and Neubauer, D. (1990) Prognosis and Risk Factors in Febrile Convulsions: A Prospective Study of 150 Children in Kuwait. Neuroepidemiology, 9, 78-87. http://dx.doi.org/10.1159/000110754

[22] Forsgren, L., Sidenvall, R., Blomquist, H.K., Heijbel, J. and Nystrom, L. (1990) An Incidence Case-Referent Study of Febrile Convulsions in Children: Genetical and Social Aspects. Neuropaediatrics, 21, 153-159. http://dx.doi.org/10.1055/s-2008-1071484

[23] Kjeldsen, M.J., Corey, L.A., Solaas, M.H., Friss, M.L., Harris, J.R., Kyvic, K.O., et al. (2005) Genetic Factors in Seizures: A Population-Based Study of 47,626 US, Norwegian and Danish Twin Pairs. Twin Research and Human Genetics, 8, 138-147. http://dx.doi.org/10.1375/1832427053738836

[24] Farwell, J.K., Blackner, G., Sulzbacher, S., Adelman, L. and Voeller, M. (1994) First Febrile Seizures, Characteristics of the Child, the Seizure and the Illness. Clinical Pediatrics, 33, 263-267. http://dx.doi.org/10.1177/000992289403300502

[25] Moller, K.L. (2008) Exanthema Subitum and Febrile Convulsions. Acta Paediatrica, 45, 534-540. http://dx.doi.org/10.1111/j.1651-2227.1956.tb06912.x 
[26] Van Zeijl, J.H., Mullart, R.A. and Galama, J.M.D. (2002) The Pathogenesis of Febrile Seizures: Is There a Role for Specific Infections? Reviews in Medical Virology, 12, 93-106. http://dx.doi.org/10.1002/rmv.346

[27] Berg, A.T. and Shinnar, S. (1996) Complex Febrile Seizures. Epilepsia, 37, 126-33. http://dx.doi.org/10.1111/j.1528-1157.1996.tb00003.x

[28] Verity, C.M., Butler, N.R. and Golding, J. (1985) Febrile Convulsions in a National Cohort Followed up from Birth. I. Prevalence and Recurrence in the First Years of Life. British Medical Journal, 290, 1307-1310. http://dx.doi.org/10.1136/bmj.290.6478.1307

[29] Chung, B., Wat, L.C. and Wong, V. (2006) Febrile Seizures in Southern Chinese Children: Incidence and Recurrence. Pediatric Neurology, 34, 121-126. http://dx.doi.org/10.1016/j.pediatrneurol.2005.08.007

[30] Kwong, K.L., Tong, K.S. and So, K.T. (2003) Management of Febrile Convulsion: Scene in a Regional Hospital. Hong Kong Medical Journal, 9, 319-322.

[31] Kong, C.K. and Ko, C.H. (2000) Local Data on Febrile Convulsion. HKCNDP Education Bulletin, 1, 6-8.

[32] Chan, K.K., Cherk, S.W.W., Chan, C.H., Ng, D.K.K. and Ho, J.C.S. (2007) A Retrospective Review of First Febrile Convulsion and Its Risk Factors for Recurrence in Hong Kong Children. HK Journal of Paediatrics, (New Series), 12, 181-187. http://www.hkjpaed.org/pdf

[33] Tosun, A., Koturoglu, G., Serdaroglu, G., Polat, M., Kurugol, Z., Gokben, S. and Tekgul, H. (2010) Ratios of Nine Risk Factors in Children with Recurrent Febrile Seizures. Pediatric Neurology, 43, 177-182. http://dx.doi.org/10.1016/j.pediatrneurol.2010.05.07

[34] Obi, J.O., Ejeheri, A. and Alakija, W. (1994) Childhood Febrile Seizures (Benin City Experience). Annals of Tropical Paediatrics, 14, 211-214.

[35] Al-Ajlouni, S.F. and Kodah, I.H. (2000) Febrile Convulsions in Children. Neurosciences, 5, 151-155. http://www.researchgate.net/publication/11843630_Febrile_convulsions_in_children

[36] Saidulhaque (1981) Febrile Convulsions. Pakistan Pediatric Journal, 5, 15-55. http://www.ayubmed.edu.pk/JAMC/PAST/14-4/Tahir.htm

[37] Johnson, E.W., Dubovsky, J. and Rich, S.S. (1998) Evidence for a Novel Gene for Familial Febrile Convulsions, FEB2, Linked to Chromosome 19P in an Extended Family from the Midwest. Human Molecular Genetics, 7, 63-68. http://dx.doi.org/10.1093/hmg/7.1.63

[38] Al-Eissa, Y.A. (1995) Lumbar Puncture in the Clinical Evaluation of Children with Seizures Associated with Fever. Pediatric Emergency Care, 11, 347-350. http://dx.doi.org/10.1097/00006565-199512000-00004

[39] Green, S.M., Rothrock, S.G., Clem, K.J., Zurcher, R.F. and Mellick, L. (1993) Can Seizures Be the Sole Manifestation of Meningitis in Febrile Children? Pediatrics, 92, 527-534.

[40] Rosenberg, N.M., Meert, K., Marino, D. and De Baker, K. (1992) Seizures Associated with Meningitis. Pediatric Emergency Care, 8, 67-69. http://dx.doi.org/10.1097/00006565-199204000-00002

[41] Wong, M., Schlaggar, B.L., Buller, R.S., Storch, G. A. and Landt, M. (2000) Cerebrospinal Fluid Protein in Pediatric Patients: Defining Clinically-Relevant Reference Values. Archives of Pediatrics and Adolescent Medicine, 154, 827831. http://dx.doi.org/10.1001/archpedi.154.8.827

[42] Devinsky, O., Nadi, S., Theodore, W.H. and Porter, R.J. (1988) Cerebrospinal Fluid Pleocytosis Following Simple, Complex Partial, and Generalized Tonic-Clonic Seizures. Annals of Neurology, 23, 402-403. http://dx.doi.org/10.1002/ana.410230418

[43] Rider, L.G., Thapa, P.B., Del Beccaro, M.A., Gale, J.L., Foy, H.M. and Farwell, J.R. (1995) Cerebrospinal Fluid Analysis in Children with Seizures. Pediatric Emergency Care, 11, 226-229. http://dx.doi.org/10.1097/00006565-199508000-00009

[44] Mohammad, M., Mohebbi, M.R. and Naderi, F. (2003) CSF Glucose Concentrations in Infants with Febrile Convulsions and the Possible Effects of Acetaminophen. Indian Pediatrics, 40, 1183-1185.

[45] Rutter, N. and Smales, O.R.C. (1976) Calcium, Magnesium and Glucose Levels in Blood and CSF of Children with Febrile Convulsions. Archives of Disease in Childhood, 51, 141-143. http://dx.doi.org/10.1136/adc.51.2.141

[46] Hall, C., Caserta, M. and Schnabel, K. (2008) Chromosomal Integration of Human Herpesvirus 6 Is the Major Mode of Congenital Human Herpesvirus 6 Infection. Pediatrics, 122, 513-520. http://dx.doi.org/10.1542/peds.2007-2838

[47] Jaworska, J., Gravel, A. and Flamand, L. (2010) Divergent Susceptibilities of Human Herpesvirus 6 Variants to Type I Interferons. Proceedings of the National Academy of Sciences of the United States of America, 107, 8369-8374. http://dx.doi.org/10.1073/pnas.0909951107

[48] Hall, C.B., Long, C.E., Schnabel, K.C., Caserta, M.T., Mclntyre, M.K., Costanzo, M.A., Knott, A., Dewhurst, S., Insel, R.A. and Epstein, G.L. (1994) Human Herpesvirus-6 Infection in Children: A Prospective Study of Complications and 
Reactivation. New England Journal of Medicine, 331, 432-438. http://dx.doi.org/10.1056/NEJM199408183310703

[49] Teach, S.J., Wallace, H.L., Evans, M.J., Duffner, P.K., Hay, J. and Faden, H.S. (1999) Human Herpesviruses 6 \&7 and Febrile Seizures. Pediatric Neurology, 21, 699-703. http://dx.doi.org/10.1016/S0887-8994(99)00068-5

[50] Hukin, J., Farrell, K., MacWilliam, L.M., Calbourne, M., Waida, E., Tan, R., Mroz, L. and Thomas, E. (1998) Case-Control Study of Primary Human Herpesvirus-6 Infection in Children with Febrile Seizures. Pediatrics, 101, e3. http://dx.doi.org/10.1542/peds.101.2.e3 